\title{
PROGRAM EMPATHY CHARACTER BUILDING UNTUK MENURUNKAN PERILAKU BULLYING PADA SISWA SMP INKLUSI
}

\author{
Faizah $^{1}$, Ulifa Rahma ${ }^{2}$, Yunita Kurniawati ${ }^{3}$ \\ Fakultas Ilmu Sosial dan Ilmu Politik, Universitas Brawijaya \\ Jalan Veteran, Malang 65145 \\ 1faizah_hermawan@ub.ac.id, ${ }^{2}$ ulifa.rahma@gmail.com, ${ }^{3}$ yufrans@yahoo.com.
}

\begin{abstract}
Bullying that frequently occurs in schools has negative impacts on students. Several intervention programs have been applied to reduce bullying. Empathy Character Building Program is a learning process to manage the empathy character of students to reduce their bullying behavior. This study aims to determine the effectiveness of Empathy Character Building Program to reduce bullying on students in grade seven. The participants were 18 seventh graders of an inclusive junior high school. Pretestposttest experimental group design was applied in this study. The results show that there is a significant effect of Empathy Character Building Program on the decrease of bullying behavior among grade seven students in an inclusive junior high school.
\end{abstract}

Keywords: bullying, empathy character building, inclusive junior high school

\begin{abstract}
Abstrak
Perilaku bullying yang banyak terjadi di sekolah-sekolah membawa dampak negatif bagi siswa. Banyak program-program intervensi yang telah di aplikasikan untuk menurunkan perilaku bullying. Program Empathy Character Building merupakan proses pembelajaran mengelola karakter empati siswa yang berfungsi untuk mengurangi perilaku yang berfokus pada perilaku bullying. Penelitian ini bertujuan untuk mengetahui efek program Empathy Character Building terhadap penurunan perilaku bullying. Subjek penelitian adalah siswa kelas VII SMP Inklusi sebanyak 18 siswa yang memiliki teman berkebutuhan khusus di kelas. Penelitian ini menggunakan Pretest Posttest Experiment Group Design. Hasil penelitian menunjukkan bahwa terdapat pengaruh program Empathy Character Building terhadap penurunan perilaku bullying pada siswa kelas VII SMP Inklusi.
\end{abstract}

Kata Kunci: empathy character building, perilaku bullying, sekolah SMP inklusi

\section{Pendahuluan}

Perilaku bullying sampai saat ini menjadi kajian yang terus berkembang seiring dengan terjadinya tindakan perilaku bullying di berbagai area khususnya di lingkungan sekolah. Komisi Perlindungan Anak Indonesia (KPAI) menyampaikan bahwa pada 
tahun 2017, International Center for Research on Women (ICRW) melakukan survei yang memperoleh hasil kekerasan anak banyak terjadi di sekolah, yaitu mencapai $84 \%$ dan merupakan persentase tertinggi dibandingkan dengan Negara Vietnam, Nepal, Kamboja, dan Pakistan (Setyawan, 2017).

Kejadian perilaku bullying sebagai alarm yang terus menjadi perhatian dari semua kalangan, karena perilaku bullying memiliki dampak yang berkelanjutan. Sebagaimana kajian Berthold \& Hoover (2000) perilaku bullying memiliki efek jangka pendek diantaranya adalah depresi pada korban, serta perubahan aktivitas siswa di sekolah yang berupa menurunnya minat dalam menyelesaikan tugas-tugas dan ketertarikan untuk mengikuti kegiatan. Selain itu akibat jangka panjang dari penindasan kesulitan dalam hubungan sosial yang meliputi kesulitan membina hubungan dengan lawan jenis dan kecemasan akan diperlakuan secara tidak menyenangkan oleh teman sebaya. Oleh karena itu perilaku bullying yang menimbulkan ancaman masalah psikis maupun fisik sebaiknya dicegah.

Pada kenyataannya saat ini perilaku bullying masih sangat marak terjadi dan kurang mendapat perhatian serius sehingga berakibat buruk bagi anak itu sendiri dan lingkungannya. Dalam lingkup sekolah, sebagian siswa menjadi korban, sedangkan siswa yang lain menjadi pelaku dan menyaksikan perilaku bullying. Wiyani (2012) mengemukakan persepsi yang belum sama antara sekolah, orang tua maupun lingkungan sosial dalam memandang perilaku bullying dan cara mengatasinya menjadi salah satu faktor yang mengakibatkan melonjaknya kasus perilaku bullying. Faktor pemerintah juga memperkuat kondisi ini dengan belum adanya kebijakan penanganan yang komprehensif dan berkesinambungan. Perilaku bullying diprediksikan akan semakin meningkat karena kekurangseriusan berbagai pihak termasuk orang tua ataupun orang dewasa lain.

Kajian kekerasan siswa SMP di tiga kota besar menunjukkan terjadinya kekerasan, yaitu Daerah Istimewa Yogyakarta sebesar 77,5\%, Surabaya sekitar 59,8\%, dan Jakarta 61,1\% (Wiyani, 2012). Menurut hasil penelitian di Australia mengenai perilaku bullying di sekolah, menunjukkan adanya peningkatan perilaku bullying pada awal memasuki masa sekolah menengah pertama (Peterson \& Rigby, 1999). Hal ini didukung oleh penelitian Nansel et al. (2001) dan Pellegrini \& Bartini (2000) yang menjelaskan bahwa perilaku bullying yang ditinjau berdasar perspektif perkembangan akan meningkat dan mencapai puncaknya pada masa remaja awal. Rigby (2007) juga menjelaskan bahwa perilaku bullying yang dilakukan oleh teman sebaya paling banyak dilakukan oleh siswa yang berumur 13 sampai 14 tahun dari rentang usia antara 10 sampai 17 tahun.

Berdasarkan data awal yang diperoleh melalui wawancara dengan guru di kelas VII di salah satu SMP Inklusi di Daerah Malang pada tahun 2015-2016, siswa-siswa kelas VII masih menunjukkan kurangnya penerimaan terhadap adanya siswa berkebutuhan khusus. Perilaku yang sering ditampilkan seperti menertawakan kelemahan fisik, tidak mengajak bermain, memanggil dengan nama yang tidak sebenarnya, dijadikan bahan lelucon, sementara siswa berkebutuhan khusus tersebut cenderung tidak berdaya.

Perilaku bullying terjadi karena adanya kekuatan dan ketidakberdayaan. Korban bullying lebih lemah secara fisik dan mental daripada pelaku, termasuk siswa berkebutuhan khusus lebih rentan mendapatkan perilaku bullying oleh teman-temannya (Rose \& Monda-Amaya, 2012). Fink, Deighton, Humphrey, \& Wolpert (2015) mengemukakan dalam perilaku bullying jumlah pelaku lebih dominan dibandingkan 
korban. Perilaku bullying dapat dilakukan oleh individu maupun berkelompok. Siswa laki-laki dan perempuan mendapatkan perilaku bullying dengan frekuensi yang hampir sama, namun jumlah pelaku yang berbeda, pada siswa laki-laki akan mendapatkan perilaku bullying dari individu ataupun kelompok, sedangkan siswa perempuan cenderung mendapatkan perilaku bullying secara berkelompok (Rigby, 2007).

Penanganan perilaku bullying banyak dilakukan oleh peneliti-peneliti sebelumnya sebagai pilihan tawaran dalam mengatasi perilaku bullying di sekolah. Studi sebelumya yang dilakukan oleh Evans, Fraser, \& Cotter (2014) memperoleh hasil program penanganan perilaku bullying dari berbagai artikel yang direview menunjukkan bahwa penerapan intervensi perilaku bullying di luar Negara Amerika Serikat dengan sampel yang homogen lebih berhasil daripada Negara Amerika Serikat dengan sampel yang heterogen.

Selanjutnya penelitian meta-analisis tentang anti-perilaku bullying school program dari Jiménez-Barbero, Ruiz-Hernández, Llor-Zaragoza, Pérez-García, \& LlorEsteban (2016) menunjukkan kegiatan penanganan bullying yang dilakukan dari berbagai program menghasilkan manfaat dengan evaluasinya masing-masing. Program intervensi yang dibahas dalam meta-analisis yang dikaji terdapat 14 penelitian program intervensi perilaku bullying.

Dengan berbagai macam tawaran solusi yang ditawarkan dari penelitian sebelumnya, angka kejadian perilaku bullying masih kerap terjadi karena kurangnya rasa iba dan empati terhadap orang lain sebagai akibat dari pandangan bahwa perilaku bullying biasa dilakukan oleh anak-anak (Goodwin, 2009). Salah satu karakter yang berperan terhadap penurunan perilaku bullying adalah empati, sebagaimana hasil studi meta-analisis Andayani (2012) yang mendukung hipotesis pada studi-studi primer sebelumnya dengan hasil bahwa empati berkorelasi negatif terhadap perilaku bullying, bahwa meningkatnya empati maka akan diikuti dengan menurunnya perilaku bullying, sebaliknya menurunnya empati akan meningkatkan perilaku bullying. Berdasarkan penelitian tersebut seseorang yang memiliki empati tinggi tidak akan membiarkan orang lain dalam kesulitan, sehingga tidak akan terlibat dalam perilaku bullying yang akan melukai atau membuat orang lain menderita.

Empati merupakan salah satu jawaban yang dapat membantu dalam mengatasi perilaku bullying di sekolah. Andayani (2012) mengemukakan bahwa remaja yang memiliki empati tinggi akan menunjukkan perilaku bullying rendah dan sebaliknya. Pengamatan di lapangan, di sekolah inklusi terlihat empati siswa regular pada siswa berkebutuhan khusus lebih tinggi dari siswa di sekolah eksklusif. Diduga empati siswa dipengaruhi oleh interaksi dengan siswa berkebutuhan khusus di kelas inklusif.

Anak yang memiliki empati yang kuat akan peduli terhadap kesusahan orang lain sehingga ia tidak melakukan perilaku yang dapat melukai orang lain (Goleman, 2006). Empati dalam diri siswa yang diharapkan berperan dalam menurunkan perilaku bullying sehingga melatarbelakangi peneliti untuk melaksanakan Program Empathy Character Building mengacu pada penelitian sebelumnya (Stanbury, Bruce, Jain, \& Stellern, 2009). Pada penelitian tersebut, pengembangan empati memiliki dampak positif dalam menurunkan bullying, subjek menjadi berkurang melakukan perilaku bullying. Hal ini didukung oleh penelitian Dautenhahn, Woods, \& Kaouri (2007) yang menjelaskan bahwa orang yang melakukan perilaku bullying kurang memiliki keterampilan empati. Randall (1997) juga mengungkapkan bahwa orang yang melakukan perilaku bullying kurang memahami dan memikirkan perasaan orang lain dan kurang memiliki kesadaran diri terkait apa yang dirasakan orang lain. 
Sebaliknya empati yang rendah pada seorang anak akan membuatnya kurang mampu menghadapu tekanan dan ikut merasakan ketidaknyamanan orang lain yang menjadi korban perilaku bullying, mereka tidak mampu mengkaitkan perilaku antisosial yang dilakukan dengan reaksi emosional orang lain (Jolliffe \& Farrington, 2006). Georgiou \& Stavrinides (2012) menyampaikan bahwa pelaku bullying tidak dapat mengenal situasi kondisi yang berbahaya atau menyakitkan bagi orang lain Hal ini sejalan dengan pernyataan Mitsopoulou \& Giovazolias (2015) bahwa perilaku bullying dipengaruhi baik oleh komponen afektif maupun kognitif, yang senada dengan konsep empati menurut Bryant (Faizah, Kurniawati, \& Rahma, 2017). Dalam konteks perilaku bullying pada komponen afekti ditunjukkan dengan ketidakmampuan pelaku untuk merasakan kondisi emosional dan rasa sakit sebagaimana yang dialami oleh korban. Sedangkan komponen kognitif ditunjukkan dengan ketidakmampuan pelaku bullying dalam memahami dan menilai emosi korban.

Program Empathy Character Building dalam penelitian ini diadopsi dari rancangan Stanbury et al. (2009) tentang empathy building on bullying behaviors dengan penyesuaian berdasar situasi kondisi yang ada di sekolah Inklusi. Program Empathy Character Building ini dirancang oleh peneliti dalam modul program yang meliputi dua tahapan utama yaitu pemahaman empati secara kognitif dan afektif; yang selanjutnya pelaksanaan empati dalam perilaku bullying yang terdiri dari tujuh sesi kegiatan dengan refleksinya. Program ini dirancang mengacu pada integrasi konsep empati, perilaku bullying dan perkembangan siswa, yang berisi usaha-usaha coping dengan dibantu peralatan yang mudah dioperasikan secara audiovisual maupun peralatan intervensi dalam roleplay, games, dan story telling.

Berdasarkan uraian tersebut, penelitian ini ingin mengetahui efek penerapan program Empathy Character Building dalam menurunkan perilaku bullying pada siswa kelas VII SMP inklusi.

\section{Metode Penelitian}

Partisipan penelitian ini adalah 18 siswa kelas VII sekolah menengah pertama Inklusi. Siswa kelas ini memiliki kecenderungan sebagai pelaku dan sebagian sebagai korban perilaku bullying. Sebanyak 18 siswa-siswi ini dipilih sebagai kelompok eksperimen karena hanya kelas inilah yang terdapat siswa berkebutuhan khusus sebagai kriteria dalam purposive sampling.

Penelitian ini menggunakan desain quasi eksperimen, pretest posttest experiment group desain. Gambaran desain penelitian ini dimulai dari pemberian pretest skala perilaku bullying di kelas, selanjutnya pelaksanaan intervensi sesuai dengan proses yang dibentuk dalam modul Program Empathy Character Building selama kurun waktu dua minggu, terakhir pemberian posttest skala perilaku bullying di kelas.

Prosedur penelitian dibagi menjadi tiga bagian yaitu: 1) persiapan, 2) pelaksanaan penelitian, 3) analisis data.

1. Persiapan Penelitian

Prosedur operasional yang dilakukan peneliti dalam persiapan penelitian ini adalah sebagai berikut:

a. Melakukan need analysis permasalahan yang ada dilapangan berkaitan dengan perilaku bullying, dan mempersiapkan intervensi Program Emphaty Character 
Building dengan menyusun modul Emphaty Character Building mengacu pada konsep program dari Stanbury et al. (2009) serta mempertimbangkan hasil penelitian sebelumnya tentang empati di berbagai jenjang pendidikan khususnya SMP (Faizah et al., 2017). Isi dari Program Empathy Character Building terdiri dari dua tahap yaitu tahap satu, penanaman empati sebagai dasar pengetahuan dan perilaku; tahap dua, Empathy Character Building terkait perilaku bullying melalui tujuh sesi kegiatan. Sebelum pelaksanaan eksperimen disiapkan seluruh keperluan eksperimen dalam hal alat-alat yang digunakan mulai dari lembar kerja, audiovisual, film pendek, media games, dan reward bagi partisipan penelitian.

b. Instrumen perilaku bullying dibuat dengan mengacu pada konsep perilaku bullying dari Rigby (2007) yang terdiri dari komponen perilaku secara fisik yang meliputi menendang, memukul dan menganiaya; secara verbal meliputi menghina, menggosip, dan memberikan nama ejekan; secara isyarat tubuh meliputi mengancam dengan gerakan, gertakan; secara berkelompok meliputi membentuk koalisi, membujuk orang lain untuk mengucilkan seseorang. Skala perilaku bullying berjumlah 23 item dengan nilai korelasi item total kisaran 0.296-0.789 dan reliabilitas sebesar 0.916 dengan contoh item 'Saya akan membicarakan teman berkebutuhan khusus sebagai bahan lelucon'. Ketika skor perilaku bullying tinggi maka menunjukkan perilaku bullying yang tinggi, dan sebaliknya.

2. Pelaksanaan Penelitian

Tahap pelaksanaan penelitian terdiri dari pelaksanaan intervensi atau proses eksperimen yaitu awal mula mengisi kuesioner pretest perilaku bullying, selanjutnya pemberian intervensi pada kelompok eksperimen berupa Program Emphaty Character Building yang dilakukan dalam dua tahap. Tahap pertama tentang penanaman empati sebagai dasar pengetahuan dan perilaku dalam bersikap terhadap siswa berkebutuhan khusus secara kognitif dan afektif. Tahap kedua berupa pelaksanaan Program Empathy Character Building sebanyak tujuh sesi, dan terakhir mengisi kuesioner posttest tentang perilaku bullying.

3. Analisis Data

Analisa data penelitian ini menggunakan uji Wilcoxon dengan menggunakan aplikasi SPSS for windows 22.0.

\section{Hasil dan Pembahasan}

Berdasarkan analisis data, diketahui bahwa nilai Z berkisar $-3.580(\mathrm{p}<0.05)$. Hasil ini menunjukkan bahwa Program Empathy Character Building memiliki pengaruh terhadap penurunan perilaku bullying pada siswa SMP Inklusi.

Tabel 1

Hasil uji Wilcoxon

\begin{tabular}{ll}
\hline Statistic & Posttest -Pretest \\
\hline$Z$ & -3.580 \\
Asymp. Sig. (2-tailed) & .000 \\
\hline
\end{tabular}

Data deskriptif antara nilai rata rata bullying sebelum eksperimen $(M=38.11$, $S D=8.50)$ dan sesudah eksperimen $(M=33.39, S D=8.37)$ menunjukkan perbedaan. Hasil 
ini menerangkan adanya penurunan nilai rata rata bullying sebesar 4.72 sesudah diberikan program Empathy Character Building sehingga perilaku bullying pada siswa SMP Inklusi menunjukkan penurunan setelah mengikuti program.

Tabel 2

Statistik deskriptif perilaku bullying sebelum dan sesudah Program Empathy Character Building

\begin{tabular}{lllll}
\hline Statistic & Mean & Standar Deviation & Minimum & Maximum \\
\hline Pretest & 38.11 & 8.505 & 24.00 & 51.00 \\
Posttest & 33.39 & 8.374 & 23.00 & 48.00 \\
\hline
\end{tabular}

Hasil analisis penelitian ini selaras dengan penelitian Stanbury et al. (2009), bahwa perilaku bullying dapat dikurangi dengan program pembangunan empati. Subjek penelitian ini telah mengalami penurunan perilaku bullying setelah mengikuti program pembangunan empati.

Program Empahty Character Building tidak hanya diwujudkan dengan pemahaman anak mengenai pengetahuan tentang empati namun juga tertanam dalam karakter anak dan terwujud dalam perilaku empati. Pada saat melihat perilaku bullying anak tidak hanya diam tetapi anak diajarkan bagaimana mencegah perilaku bullying terjadi dengan lebih peka, memahami orang lain serta menolong orang lain dalam kondisi tersebut. Bahkan ketika anak pernah menjadi pelaku sekalipun, akan tersadar bahwa apa yang dilakukan salah dan ia dapat memposisikan diri sebagai korban ketika empati sudah tertanam. Sebagaimana penelitian sebelumnya (Andayani, 2012) yang menunjukkan empati berkorelasi secara negatif dengan perilaku bullying. Empati memiliki peran yang penting dalam menurunkan perilaku bullying, jika anak memiliki empati yang tinggi maka perilaku bullying rendah sehingga empati ini sebagai salah satu karakter yang dapat membantu meminimalisir perilaku bullying.

Empati tidak muncul secara tiba-tiba karena membutuhkan sebuah proses, termasuk bagi siswa yang melakukan perilaku bullying. Siswa yang sudah terbiasa melakukan perilaku bullying memiliki kecenderungan sikap kurang peduli terhadap situasi sosial yang ada dilingkungannya. Hasil penelitian Dautenhahn et al. (2007) menerangkan seseorang yang melakukan perilaku bullying, kurang memiliki keterampilan empati. Randall (1997) juga menyatakan bahwa seseorang yang berperilaku bullying cenderung kurang memahami dan memikirkan perasaan orang lain serta kurang memiliki kesadaran diri terkait apa yang dirasakan orang lain. Sehingga salah satu cara untuk menangani masalah perilaku bullying adalah melalui pembentukan karakter empati. Empati merupakan salah satu bagian penting dalam social life skill. Empati menjadi bagian utama dari inti emosi moral yang membantu anak memahami perasaan sesamanya. Anak akan semakin peka terhadap kebutuhan dan perasaan orang lain, terdorong untuk membantu orang yang kesusahan atau kesulitan, serta untuk dapat memperlakukan orang lain dengan kasih saying dengan adanya empati.

Pelaksanaan program Emphaty Character Building dalam penelitian ini mengadaptasi secara langsung dari konsep emphaty building program on bullying behavior (Stanbury et al., 2009). Program Emphaty Character Building dalam penelitian ini mengkaji permasalahan perilaku bullying secara umum. Program ini semakin optimal jika konteks isi program disesuaikan dengan kondisi yang ada dimasing masing sekolah seperti memodifikasi modul sesuai dengan permasalahan perilaku bullying yang ada di sekolah tersebut. 


\section{Simpulan}

Program Emphaty Character Building dapat menurunkan perilaku bullying pada siswa SMP Inklusi kelas VII. Program Emphaty Character Building dalam penelitian ini mengkaji permasalahan aktifitas perilaku bullying di sekolah. Rancangan modul program Empathy Character Building pada siswa kelas VII SMP Inklusi dapat diterapkan di sekolah inklusi yang lain untuk membantu mengatasi perilaku bullying pada siswa. Rancangan modul ini dapat dikembangkan pada kegiatan yang dilaksanakan di sekolah dasar inklusi dengan dilakukan modifikasi isi kegiatannya sesuai dengan permasalahan yang ada di sekolah dan memperhatikan jenjang pendidikan siswa.

\section{Daftar Pustaka}

Andayani, T. R. (2012). Studi meta-analisis: Empati dan bullying. Buletin Psikologi, 20(1-2), 35-51. https://doi.org/10.22146/bpsi.11947

Berthold, K. A., \& Hoover, J. H. (2000). Correlates of bullying and victimization among intermediate students in the Midwestern USA. School Psychology International, 21(1), 65-78. https://doi.org/10.1177/0143034300211005

Dautenhahn, K., Woods, S. N., \& Kaouri, C. (2007). Bullying behaviour, empathy and imitation: An attempted synthesis. In Imitation and Social Learning in Robots, Humans and Animals: Behavioural, Social and Communicative Dimensions (pp. 323-340). https://doi.org/10.1017/CBO9780511489808.021

Evans, C. B. R., Fraser, M. W., \& Cotter, K. L. (2014). The effectiveness of schoolbased bullying prevention programs: A systematic review. Aggression and Violent Behavior, 19(5), 532-544. https://doi.org/10.1016/j.avb.2014.07.004

Faizah, Kurniawati, Y., \& Rahma, U. (2017). Empati terhadap siswa berkebutuhan khusus: Ditinjau dari jenjang pendidikan inklusi dan jenis kelamin. Jurnal Psikologi Undip, 16(1), 1-7.

Fink, E., Deighton, J., Humphrey, N., \& Wolpert, M. (2015). Assessing the bullying and victimisation experiences of children with special educational needs in mainstream schools: Development and validation of the bullying behaviour and experience scale. Research in Developmental Disabilities, 36, 611-619. https://doi.org/10.1016/j.ridd.2014.10.048

Georgiou, S. N., \& Stavrinides, P. (2012). Social-psychological profiles of early adolescents involved in bullying activities. International Journal of Criminology and Sociology, 1, 60-68.

Goleman, D. (2006). Emotional intelligence. New York: Bantam Books.

Goodwin, D. (2009). Strategies to deal with bullying. Sidney, Wellington:Kidsreach Inc.

Jiménez-Barbero, J. A., Ruiz-Hernández, J. A., Llor-Zaragoza, L., Pérez-García, M., \& Llor-Esteban, B. (2016). Effectiveness of anti-bullying school programs: A meta-analysis. Children and Youth Services Review, 61, 165-175. 
https://doi.org/10.1016/j.childyouth.2015.12.015

Jolliffe, D., \& Farrington, D. P. (2006). Examining the relationship between low empathy and bullying. Aggressive Behavior, 32(6), 540-550. https://doi.org/10.1002/ab.20154

Mitsopoulou, E., \& Giovazolias, T. (2015). Personality traits, empathy and bullying behavior: A meta-analytic approach. Aggression and Violent Behavior. https://doi.org/10.1016/j.avb.2015.01.007

Nansel, T. R., Overpeck, M., Pilla, R. S., Ruan, W. J., Simons-Morton, B., \& Scheidt, P. (2001). Bullying behaviors among US youth: Prevalence and association with psychosocial adjustment. Journal of the American Medical Association, 285(16), 2094-2100. https://doi.org/10.1001/jama.285.16.2094

Pellegrini, A. D., \& Bartini, M. (2000). An empirical comparison of methods of sampling aggression and victimization in school settings. Journal of Educational Psychology, 92(2), 360-366. https://doi.org/10.1037/0022-0663.92.2.360

Peterson, L., \& Rigby, K. (1999). Countering bullying at an Australian secondary school with students as helpers. Journal of Adolescence, 22(4), 481-492. https://doi.org/10.1006/jado.1999.0242

Randall, P. (1997). Adult bullying: Perpetrators and victims. New York: Routledge.

Rigby, K. (2007a). Bullying in schools: and what to do about it. Victoria Australia: ACER Press. Retrieved from https://books.google.co.id/books?redir_esc=y\&hl=id\&id=KEUeLn09668C\&q=d imention+of+bullying\# $\mathrm{v}=$ onepage $\& \mathrm{q}=$ dimention of bullying $\& \mathrm{f}=$ false

Rigby, K. (2007b). Bullying in Schools: and what to do about it. National Library of Australia, 22, 1-330. https://doi.org/10.2753/EUE1056-4934220192

Rose, C. A., \& Monda-Amaya, L. E. (2012). Bullying and victimization among students with disabilities: Effective strategies for classroom teachers. Intervention in School and Clinic, 48(2), 99-107. https://doi.org/10.1177/1053451211430119

Setyawan, D. (2017). Indonesia peringkat tertinggi kasus kekerasan di sekolah. Komisi Perlindungan Anak Indonesia. Retrieved from http://www.kpai.go.id/berita/indonesia-peringkat-tertinggi-kasus-kekerasan-disekolah

Stanbury, S., Bruce, M. A., Jain, S., \& Stellern, J. (2009). The Effects of an empathy building program on bullying behavior. Journal of School Counseling, 7(2), 127. Retrieved from https://eric.ed.gov/?id=EJ886113

Wiyani, N. A. (2012). Save our children from school bullying. Yogyakarta: Ar-Ruzz Media. 